\title{
Short Vowels and Context Effects: The Case of English Speakers Reading Arabic
}

\author{
Asmaa Shehata ${ }^{1}$ \\ ${ }^{1}$ The Department of Modern Languages, The University of Mississippi, Oxford, USA \\ Correspondence: Asmaa Shehata, The Department of Modern Languages, The University of Mississippi, Oxford, \\ MS., 38677-1848, USA. Tel: 1-662-915-1701. E-mail: akshehat@olemiss.edu
}

Received: April 8, 2021

doi:10.5539/ies.v14n8p93
Accepted: May 14, $2021 \quad$ Online Published: July 30, 2021

URL: https://doi.org/10.5539/ies.v14n8p93

\begin{abstract}
The present study examines the impact of both short vowels and context on adult native English speakers' reading accuracy of Arabic orthography. To this end, two groups of adult Arabic learners with different proficiency levels were recruited: 30 second-year, and 30 third-year learners. Subjects were instructed to read 50 isolated words, 20 sentences and 10 paragraphs in two different reading conditions: vocalized and unvocalized. Findings demonstrated a significant positive influence of both short vowels and context on second-year learners' word recognition of the target stimuli. That is, second year Arabic learners had better accuracy when reading vocalized texts compared to unvocalized ones and were significantly more accurate at reading paragraphs and sentences than isolated words. However, third-year students' reading accuracy was only significantly affected by the reading context.
\end{abstract}

Keywords: short vowels, Arabic orthography, modern standard Arabic, reading context, reading accuracy

\section{Introduction}

Reading is one of the major language skills that is essential for language learners. As a receptive skill, reading is considered an interactive process that involves various mental processes such as phonological and lexical decoding of letter segments. That is, written symbols are converted to units of sounds and are also connected to their lexical meanings (Aebersold \& Field, 1997; Nation \& Snowling, 2004). By doing so, reading associates readers' minds with the texts they read (Carrell et al., 1988), and therefore it is described as a demanding cognitive process (Cairns \& Adams, 1991; Perfetti \& Rieben, 1991).

Languages' writing systems, however, reflect how their phonology and orthography are matched. Whereas some orthographies are transparent or shallow (e.g., Spanish) with one-to-one relationship between graphemes and phonemes, others are opaque or deep (e.g., English) with indirect relationship between the letters and their sounds (Taouka \& Coltheart, 2004). In this respect, numerous studies have indicated that orthography consistently seems to affect the reading acquisition process. According to Hansen (2008), for example, reading a deep orthography is found to be challenging for second language (L2) learners because it requires connecting letters with their sounds, which negatively influences the reading process. Moreover, "word decoding necessitates the use of large-unit orthographic units (such as morphemes) for the retrieval of word pronunciation" (Ibrahim, 2013, p. 248). In contrast, reading a shallow orthography is found to be less difficult because it requires readers to apply "a simple process of phonological computation" (Ibrahim, 2013, p. 249). In other words, it is easier for second language learners to read shallow orthography than deep orthography.

Reading in Arabic, however, is unique. Whereas vocalized script is depicted as a shallow orthography, unvocalized Arabic script is known as a deep orthography. Thus, reading in Arabic offers an excellent opportunity for examining the relationship between two types of orthographies within one language rather than across languages which is the focus of this paper.

\subsection{Arabic Language}

Arabic is written from right to left and its alphabet includes 28 letters (Azzam, 1993; Ryding, 2005). In general, words in Arabic are written in a consonantal alphabet that is written as "cursive characters whilst the vowels are written as diacritics attached to these cursive characters, above or below them" (Taouka \& Coltheart, 2004, p. 29). There are six Arabic vowels: three short vowels and three long ones. While the long Arabic vowels are part of the 
alphabet (i.e., [aa] 'alif', [ii] 'yaa' and [uu] 'waw'), short vowels are diacritical symbols (slashes, small circles, and squiggles) appended either above (i.e., [a] 'fathah' and [u] 'd'ammah') or below the consonants (i.e., [i] 'kasrah') (Ryding, 2005). Besides their phonological roles, short vowels have grammatical functions based on their position in the sentence as they are written as roots with different affixations and they form numerous words in the lexicon (Prunet, Be'land \& Idrissi, 2000). For example, it is short vowels that can assist readers to decide if the word is a

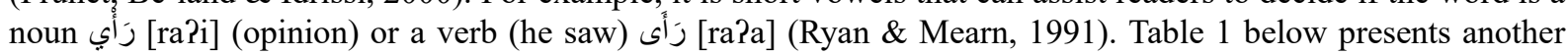
example that illustrates the significance of diacritic symbols in detecting the right pronunciation and meaning of an Arabic word.

Table 1. Example of unambiguous shallow orthography in Arabic

\begin{tabular}{|c|c|}
\hline he accepted [qabala] فَبَل & \\
\hline before [qabl] قَبْل & \\
\hline he kissed [qabbal] & قبل ق \\
\hline was accepted [qubila] قُبِ & \\
\hline kisses [qubal] & \\
\hline
\end{tabular}

In print, however, the Arabic script is typically presented with no diacritical symbols that are usually omitted except for the sacred book of Islam, i.e., the Qur'an, children's books, and some literary materials. To be able to read in Arabic, therefore, readers commonly rely on their prior knowledge and/ or the given context in their reading of the Arabic texts (Abu-Rabia, 1996; Abdulhadi, Ibrahim, \& Eviatar, 2011). Thus, the absence of short vowels presents a challenge for $\mathrm{L} 2$ learners of Arabic whose native language differs from Arabic and only includes a shallow script (Taouka \& Coltheart, 2004).

The best scenario is the case of native English speakers learning Arabic who find reading in Arabic a difficult task due to several reasons. Firstly, some letters look similar and can only be distinguished by a dot, such as the velar and the pharyngeal fricatives $\tau[\hbar]$ and $\dot{\tau}[\mathrm{x}]$, or a single stroke, like the alveolar and the postalveolar fricatives w [s] and ش $[\check{s}]$ (Ryding, 2005). For example, the word حاخ "condition" can be differentiated from the word "maternal uncle" by the presence of one dot above the letter $\dot{\tau}[\mathrm{x}]$ for the second word. Another example, similarly, the word " $ش[\check{s}]$. Secondly, the presence or absence of dots as well as their number and position, whether above or beneath the letters, do distinguish some Arabic letters. For instance, the Arabic sounds /b/, /t/, / / / and /n/ are written asن - ثـ ب respectively (Abdulhadi, Ibrahim, \& Eviatar, 2011). Thirdly, the pronunciation of the two letters و [waw], and ي [yaa] is confusing for Arabic language learners because these two letters can be used as long vowels and consonants with different pronunciations (Holes, 2004). As a long vowel, the letter يـاء [yaa] is pronounced as [ii] (e.g., the word "كَيْ "a lot”), but it is also pronounced as [y] when it stands for a consonant (e.g., "he writes"). Similarly, the letter g [waw] is pronounced as [uu] (e.g., "فو "beans") when it is a long vowel, but it is pronounced as [w] (e.g., ولـ "boy") when it stands as a consonant. Finally, the shape of some Arabic letters varies depending on their position in the word. For example, the letter [haa?] /h/ has four different shapes: one initial 'ه', one middle ' $\&$ ', and two final 'o/ $\alpha$ ' (Taouk \& Coltheart, 2004).

\subsection{Purpose of the Study and Research Questions}

The current study aimed to examine how short vowels and context (in this case, single words, sentences, and paragraphs) affect adult Arabic L2 learners' reading accuracy in order to provide an empirical basis for recommendations concerning the teaching of reading in Arabic. To this end, the following two main questions were addressed:

1) Does reading condition with vowels versus without vowels influence adult Arabic L2 learners' oral reading accuracy?

2) Does reading context affect the reading accuracy of Arabic L2 learners at different proficiency levels?

\section{Literature Review}

In the $\mathrm{L} 2$ reading learning literature, there exists much discussion on reading in Arabic by different Arabic learners. A number of studies have noted not only significant positive role of reading context in improving L1 learners' reading skills of both Roman alphabetic orthography (Bruck, 1990; Perfetti, 1985) and Arabic orthography (Abu-Rabia \& Siegel, 1995) but also short vowels were reported to facilitate reading in Arabic (Abu-Rabia, 2001). However, very few studies examined the role of short vowels and context in reading accuracy 
and fluency in Arabic orthography by adult non-native learners. The following lines present two types of studies: 1) those that investigated the reading accuracy of L1 learners of Arabic including children as well as adults, and 2) others that included non-native learners of Arabic.

\subsection{Studies in Arabic as a First Language}

Mixed results have been reported in the literature regarding the role of short vowels and context in reading Arabic orthography by L1 learners of Arabic. Whereas some studies confirmed their positive role in reading the Arabic script (Abu-Hamour, Al-Hmouz, \& Kenana, 2013), other studies indicated their negative influence on Arabic learners' reading accuracy (Taha \& Azaizah-Seh, 2017). The following lines present a discussion of these two major findings.

\subsubsection{Studies Support the Positive Contribution of Short Vowels and Context}

A considerable reading research reveals that both Arabic short vowels and context could facilitate reading in Arabic. For instance, Abu-Rabia and Siegel (1995) asked whether the reading context affects L1 Arabic learners' word recognition. To explore this question, 40 middle school students, 20 poor readers and 20 skilled readers, were instructed to read 20 sentences: 10 unvoweled and 10 voweled. Participants also read the first word in each sentence separately in two balanced conditions: voweled and unvoweled. The results revealed the significant role of context for all subjects in both groups. In other words, the reading accuracy of all subjects improved when the target stimuli were presented in context (i.e., in sentences). Although skilled Arabic readers generally performed better than their counterparts in the other group, there was no significant difference between the performance of the two groups in reading unvocalized texts.

Along the same lines, Abu-Rabia (1996) tested the effects of short vowels and reading context on L1 Arabic speakers' reading accuracy. More specifically, the study asked if short vowels and reading context could facilitate the reading accuracy of highly skilled L1 Arabic learners. To answer the research questions, 68 high school students were required to read aloud isolated words and four paragraphs under vocalized and unvocalized conditions. The results displayed that subjects' reading accuracy improved when vocalized words were presented in context. Yet, the two groups of subjects made more mistakes when they read isolated unvocalized words. Findings suggested the positive effects of context and short vowels that were reported to facilitate L1 learners' word recognition. There was also no significant difference between skilled and poor readers in reading unvoweled texts. Similarly, Abu-Rabia (1997) asked 109 tenth grade Arab students, 79 skilled readers and 39 poor readers to read aloud four Arabic newspapers articles and four narrative stories in order to further examine the influence of Arabic vowels and context on their reading accuracy. For each text that participants read, there were four reading conditions: text with vowels, text without vowels, vocalized word naming list, and unvocalized word naming list. Participants' accuracy was assessed by three testers who were native Arabic speakers. Findings reinforced the positive role of vowels and context that were found to help both poor and skilled readers perform better. The findings suggested a new reading model for skilled readers that could incorporate both sentence context and vowels. Using different reading materials, Abu-Rabia (1998) asked sixty-four native Arabic speakers who were eleventh grade students, including poor and skilled readers, to read four Arabic texts: narrative, informative, poetic, and Quranic. Texts were presented into three different reading conditions: vocalized, unvocalized, and wrongly vocalized. The results emphasized the positive role of short vowels that were found to be "a good reading facilitator more for skilled readers than for poor readers" (p.112). However, participants failed to recognize isolated words and sentences that included false short vowels which significantly impeded their reading accuracy.

\subsubsection{L1 Studies Support the Negative Contribution of Short Vowels and Context}

Nevertheless, other studies found no advantage for incorporating short vowels in L1 Arabic reading texts. For example, Seraye (2004) investigated the influence of short vowels on skilled adult L1 Arabic speakers' reading comprehension and reading accuracy. 101 adult native Arabic speakers, whose age ranged between 19 and 40, were instructed to read two long Arabic texts as well as two short Arabic texts. While two of the texts included low frequency words, the other two included high frequency words. In the second experiment, subjects read 90 sentences that included three reading conditions: 30 voweled sentences, 30 unvoweled sentences and 30 voweled sentences without shaddah. In addition, there was a word naming task afterward in which subjects read aloud isolated words as quickly as possible. Whereas some of these words included wrong vowels as well as shaddah (-), others incorporated right vowels. The results showed no influence for short vowels on subjects' reading comprehension as well as their reading accuracy. Additionally, the absence of short vowels and context hindered skilled adult readers to choose the right words in the word naming task which was not the case at the sentence and text levels. The author concluded that the reading process could be influenced by word frequency rather than short vowels. In the same vein, Taha (2016) examined the effect of short vowels on the reading fluency and accuracy of 
skilled and poor young Arabic readers. The researcher asked different groups of young Arabic students: 96 second grade, 98 fourth grade and 95 sixth graders, to read aloud a list of Arabic words and a text that were presented in two reading conditions: vocalized and unvocalized. The results showed that poor readers were more accurate in reading unvocalized texts than the vocalized ones. It was concluded that the redundant information provided by the presence of short vowels produced a highly visual load for L1 Arabic children which impeded their reading accuracy. In addition, Taha and Azaizah-Seh (2017) tested the effect of vowelization on L1 Arabic adults' word recognition performance. Researchers asked 41 adult native Arabic speakers to participate in a lexical decision task that included three types of words as well as pseudowords in three different reading conditions: vocalized, partially vocalized, and unvocalized. The results indicated that subjects performed more accurately when they read unvocalized words as well as pseudowords compared to vocalized and partially vocalized stimuli. The authors concluded with a confirmation that "reading non-vocalized texts and reading tasks may be a more effective task compared to vocalized tasks." that added extra visual load for L1 Arabic learners and consequently decreased their reading accuracy (p. 526).

\subsection{Studies in Arabic as a Foreign/Second Language}

Unlike L1 Arabic previous research on reading in Arabic orthography, very few studies have examined reading by L2 and or foreign (F) Arabic language learners. Previous studies in this area have primarily focused on two chief directions: reading strategies (Khaldieh, 1999) and reading skills (Hana, 1972; Khaldieh, 1996). For example, Hanna (1964) tested the reading errors made by 12 American students who were beginner Arabic learners. At the end of the academic year, learners were given a reading test that included two types of vocalized stimuli, i.e., 11 isolated words and 25 pairs of words, that were commonly used in Arabic newspapers and relatively familiar for subjects. The results demonstrated that L2 Arabic learners made different types of errors including incorrect vowels and consonants as well as omission of sounds. The study was concluded with an emphasis on the significance of the diagnostic test in measuring adult L2 learners' errors quantitatively. Moreover, Khaldieh (1996) investigated how Arabic script and phonology affected Arabic as a foreign language (AFL) learners' word recognition. To answer this research question, thirty-six American learners of Arabic at four different proficiency levels (beginning, intermediate, advanced and superior) participated in two experiments: one at the word level and the other at the sentence level. Results demonstrated that learners' language proficiency significantly influenced their reading accuracy. That is, less proficient L2 Arabic learners made more errors than their high proficient peers. In addition, subjects made more visual errors at the word level and more phonological errors at the sentence level. Findings, thus, suggested that the more L2 leaners practice and are exposed to the Arabic language, the better their orthographic and phonological knowledge becomes.

Hansen (2010), however, tested the impact of the Arabic writing system and vowelization on AFL learners' word recognition and reading comprehension. To this end, 71 AFL learners (i.e., 37 L1 Danish speakers, 29 L1 English speakers and five L1 German speakers) at three different proficiency levels, 27 beginners, 21 intermediate and 23 advanced, performed three tests. Firstly, they were instructed to read three passages that included Arabic pseudowords. Secondly, subjects read two stories, one unvocalized and one vocalized, that was followed by a five multiple-choice task to check their comprehension of the two texts. Thirdly, subjects were asked to choose the appropriate vowel patterns for the target pseudowords that were unvocalized. In general, subjects' performance was compared to the performance of 24 native Moroccan Arabic speakers in the control group. The findings indicated that Arabic orthography hindered AFL learners' word recognition. The absence of vowels, however, helped beginner and intermate learners improve their reading speed and comprehension, On the contrary, vowels did not significantly influence advanced learners' reading speed nor their comprehension whose performance was closer to native speakers' performance in the control group.

Several conclusions can be drawn from the findings discussed so far. Firstly, to date, most studies that examined the effect of vowelization on the readability of words in context by native Arabic learners reported conflicting findings. Whereas some studies reported the positive contribution of short vowels and context in reading Arabic for both children (Abu-Hamour, Al-Hmouz, \& Kenana, 2013) and adults (Abu-Rabia, 2001), others displayed them as distractors that added an extra mental load to learners and consequently hindered their reading accuracy of Arabic orthography (Seraye, 2016). Secondly, very few studies explored the effect of short vowels on the reading accuracy of adult L2 learners of Arabic whose L1 script considerably differs from the Arabic orthography (Hansen, 2010). Thirdly, various L1 Arabic studies reported the positive role of reading context in facilitating native Arabic speakers' reading accuracy (Abu-Rabia, 1996). Nevertheless, it is not clear whether these findings are restricted to L1 Arabic data, or it can be extended to include L2 Arabic learners as well. To better understand how the reading context impacts the reading accuracy of L2 learners of Arabic, this issue needs further research with novel tasks and different groups of learners. Therefore, the present study examined the influence of both short vowels and 
reading context on adult Arabic L2 learners' reading accuracy. It was predicted that reading voweled stimuli would help adult Arabic L2 participants to read the target texts more accurately than the unvocalized ones. It was also hypothesized that context would facilitate the reading accuracy of subjects whose scores on sentences and paragraphs would significantly outperform their scores on isolated words.

\section{Method}

An experimental study is conducted to examine the effects of Arabic short vowels and context on the reading accuracy of L2 Arabic learners, who are native English speakers. The following lines present the study's design.

\subsection{Participants}

Sixty English learners of Modern standard Arabic (35 females and 25 males) aged 19-23 took part in the present study. They were divided into two groups: 30 second-year learners (with maximum 250 hours of classroom experience) and 30 third-year learners (with maximum 350 hours of classroom experience). Subjects were at two different language proficiency levels: intermediate and advanced. They were also students at a mid-west American university who had normal and/or corrected vision as well as normal hearing. They all earned course credit for their participation. Moreover, two native Arabic speakers (one male, one female) were recruited from undergraduate linguistics and psychology courses at the same American university to assess subjects' reading accuracy.

\subsection{Stimuli}

All stimuli were real Arabic words that fell into three main lists: individual words $(\mathrm{N}=50)$, sentences $(\mathrm{N}=20)$ and paragraphs $(\mathrm{N}=10)$. While word list included a combination of Arabic verbs and nouns, each sentence included four words (See Appendices 1, 2 and 3 for the three different lists). Words in the three lists were frequently used in Arabic newspapers and were slightly familiar to subjects. All stimuli were counterbalanced for all subjects: half vocalized and half unvocalized as described in Table 2 below.

Table 2. The Counterbalanced Stimuli

\begin{tabular}{|c|c|}
\hline \multirow{5}{*}{ 2nd year learners } & 1. individual words: \\
\hline & a. twenty-five vocalized condition \\
\hline & b. twenty-five unvocalized condition \\
\hline & 2. Sentences: \\
\hline & a. ten vocalized condition \\
\hline \multirow[t]{4}{*}{3 rd year learners } & b. ten unvocalized condition \\
\hline & 3. paragraphs: \\
\hline & a. five vocalized condition \\
\hline & b. five unvocalized condition \\
\hline
\end{tabular}

\subsection{Procedures}

All participants initially filled in a demographic questionnaire about their background information such, age, gender, language background and their educational experience. Each participant then was individually recoded reading aloud the three target counterbalanced lists at their normal reading pace in the following order: individual words, sentences, and paragraphs. This process took around 30 minutes. Then, two Arabic raters wrote down the participants' errors (accuracy).

\subsection{Scoring and Reliability}

Two raters assessed subjects' reading accuracy of the target stimuli. Each correct word pronouncing earned 1 point and each incorrect one earned zero. To be scored as correct, each vocalized word had to be read correctly with consideration of all vowels. Unvoweled stimuli, however, were assessed as correct if they sounded real Arabic words.

\section{Results}

To answer the first research question that investigated the influence of vowelization on L2 Arabic learners' reading accuracy, proportion correct (proportion of subjects' reading accuracy as evaluated by the two native Arabic raters) was calculated for each participant. The data were submitted to Analysis of Variance, with readers' language level (two levels: second year versus third year) and reading condition (two levels: vocalized versus unvocalized). The analysis revealed a significant main effect of reading condition $(F(1,58)=23.256, p<.005$, partial eta 
squared=.653), with subjects' accuracy of the vocalized stimuli (.786) higher than their accuracy of the unvocalized stimuli (.453). Moreover, the main effect of language level of readers was significant $(\mathrm{F}(1,58)=35.453,(\mathrm{p}<.005$, partial eta squared $=.492)$, with third year learners' reading accuracy of the target stimuli (.868) higher than second year learners' reading accuracy (.581). The interaction of language level and reading condition was also significant $(\mathrm{F}(1,58)=39.476,(\mathrm{p}<.001$, partial eta squared $=.524)$.

Following up on the significant interaction of language level and vowelization, we will now focus on the results for each language level separately. There was a significant difference between the two reading conditions for second-year learners $(F(1,58)=42.512, p<.005$, partial eta squared $=.430)$, where subjects in this group read vocalized stimuli more accurately (.638) than the unvocalized ones (.332). Conversely, the effect of the two reading conditions on third-year subjects' performance was not significant $(F(1,58)=5.372, p=.081$, partial eta squared $=.015)$. Although third-year learners' reading accuracy was higher for the vocalized than unvocalized orthography, the difference between their reading scores in the two conditions was not statistically significant.

To answer the second research question that explored the influence of context type, proportion correct (proportion of subjects' reading accuracy as evaluated by the two language raters) was calculated for each reader. The data were submitted to Analysis of Variance, with language level (two levels: second-year versus third-year) and context type (words, sentences and paragraphs). The analysis revealed a significant main effect of context type $(\mathrm{F}(1,58)=31.891, \mathrm{p}<.005$, partial eta squared $=.560)$, with subjects' reading accuracy of paragraphs was significantly higher $(M=71.5)$ than both sentences $(M=58.9)$ and words $(M=50.7)$. In addition, the main effect of language level was significant $(\mathrm{F}(1,58)=36.424,(\mathrm{p}<.005$, partial eta squared $=.521)$. The interaction of language level and context type was significant as well $(\mathrm{F}(1,58)=11.342,(\mathrm{p}<.001$, partial eta squared $=.251)$ with subjects' reading accuracy of paragraphs, for example, increased significantly from second-year readers $(M=52.72)$ to third-year learners $(\mathrm{M}=73.82), \mathrm{p}<.005$.

Following up on the significant interaction of language level and context type, there was a significant difference between the three types of contexts for second-year learners $(\mathrm{F}(1,58)=42.512, \mathrm{p}<.001$, partial eta squared $=$. 430 ), with subjects' reading accuracy of paragraphs was higher (.577) than both sentences (.472) and isolated words (.405). Furthermore, the effect of context type on third-year subjects' performance was significant $(\mathrm{F}(1,58)$ $=3.381, \mathrm{p}<.001$, partial eta squared $=.325)$ where the percentage of learners' errors in reading isolated words (39.7\%) was higher than sentences (29.5\%) and paragraphs (14.53\%). Thus, the two groups' reading accuracy of the three types of contexts, significantly differed. Figure 1 below introduces a visualization of these results.

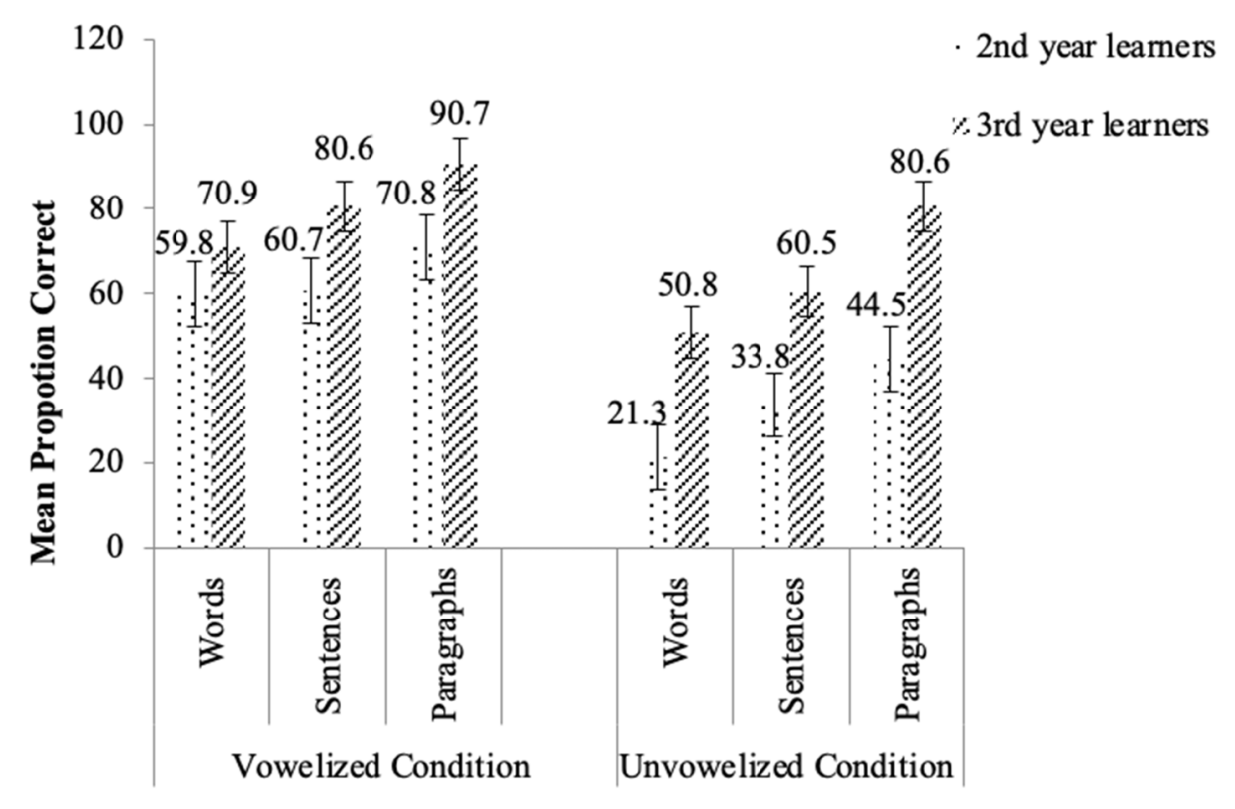

Figure 1. Proportion mean correct for subjects on list types in the two reading conditions 


\section{Discussion}

The chief goal of the present study was to examine the effects of both short vowels and context on the reading accuracy of adult L2 learners of Arabic. The first research question asked whether reading condition (vocalized versus unvocalized) can affect native English speakers' reading accuracy of Arabic isolated words, sentences and paragraphs. Findings showed the performance of second-year learners to be significantly more accurate when they read vocalized Arabic stimuli, words (.598), sentences (.607) and paragraphs (.708), than the unvocalized ones, words (.213), sentences (.338) and paragraphs (.445). While second-year learners were able to read unvocalized Arabic orthography with $33.2 \%$ accuracy (averaged across words, sentences and paragraphs), their reading accuracy was higher when they read vocalized texts with $63.8 \%$ correct that exceeded the accuracy of the unvocalized texts by 30 percentage points. Together, this finding implies that short vowels facilitate the reading accuracy of second-year learners (poor readers) for all types of contexts. This evidence supports the arguments of Abu-Rabia (1997) and (1998) that vowelization plays a positive role in empowering poor language learners' reading of different Arabic texts due to the rich language input that short vowels provide. Unlike the performance of L1 learners in Abu-Rabia (1997) and (1998) on the vocalized paragraphs whose accuracy scores were $35.64 \%$ and $33.9 \%$ respectively; second-year learners in this study successfully read vocalized paragraphs with $70 \%$ accuracy. However, leaners in that group did not achieve the same success (i.e., 43\%) with unvocalized paragraphs.

On the other hand, even though third-year learners had significantly higher reading accuracy than second-year learners in the three different contexts and their reading accuracy of vocalized Arabic texts was higher, words (.709), sentences (.806) and paragraphs (.907), than the unvocalized contexts (words (.508), sentences (.605) and paragraphs (.806), the difference between the two reading conditions was not significant. That is, vowelization did not significantly influence third-year learners' accuracy where there was no significant difference in accuracy for vocalized and unvocalized texts. These data argue against the view that considers short vowels to be facilitators of reading accuracy for advanced language learners (Abu-Rabia, 1996, 1997). Instead, short vowels, as noted here, did not play a significant role in enhancing adult learners' reading accuracy. One possible explanation for the difference between the two groups in the current study may be related to participants' language proficiency that enabled third-year students to better read target texts without relying on vowels. As readers achieved adequate mastery of the reading skills, the presence of diacritic marks did not have a significant role but rather their advanced reading strategies. On the other hand, second-year learners -whose language proficiency level was lower- lacked these advanced strategies at this language level. To compensate for their lower reading skill, therefore, they took advantage of the phonological information that short vowels provided which helped them in their phonological decoding of the target Arabic stimuli.

The second research question addressed the possible contribution of reading context to adult L2 learners' reading accuracy. The results revealed that the three groups of adult learners successfully exploited the reading context, that was provided in both sentences and paragraphs, to better read the Arabic texts. The reading context provided adult L2 Arabic readers with the morpho-syntactic information that facilitated their reading of the target Arabic texts. This result provides additional evidence supporting the positive role of context in reading Arabic orthography. In line with findings obtained by previous studies of Arabic-speaking children (Abu-Rabia \& Siegel, 1995; Abu-Rabia, 1996), the present study showed reading context to play a positive role for native Arabic speakers in their reading of Arabic orthography. This in turn provides more robust results regarding the beneficial role of context in reading Arabic and supports Abu-Rabia's claim that "reading in Arabic is not an autonomous word recognition process but a context-dependent word recognition process" (1996, p. 638).

This study was motivated in part by mixed results reported in the literature regarding the role of short vowels and context in the reading of skilled and poor Arabic readers. Considered together, the findings summarized here provide further evidence for the benefit of vowelization and context paradigm that was introduced in previous research. According to these studies, the availability vowels and context provided learners with various sources of information, such as phonological and morpho-syntactic information that resulted in improving learners' reading of the Arabic orthography. Nevertheless, the results contradict the proposal of Seraye (2004), and Taha and Azaizah-Seh (2017) that displayed the negative influence of vowelization on reading accuracy in Arabic. The difference between the results of the four studies is possibly attributed to the differences in the design of each one of them. Unlike the present study whose subjects were adult L2 learners of Arabic, the three other studies tested the reading accuracy of native Arabic learners who were either children (Abdulhadi, Ibrahim, \& Eviatar, 2011) or adults (Seraye, 2004; Taha \& Azaizah-Seh, 2017). One more reason for this difference may be related to the nature of stimuli in each study (i.e., four Arabic expository texts in Seraye (2004), real Arabic words and nonsense words in Abdulhadi, Ibrahim, and Eviatar (2011) and Taha and Azaizah-Seh (2017) versus isolated words, sentences and 
paragraphs in the present study.

\section{Limitations, Pedagogical Implications and Future Research}

Findings shed some light on the significance of both short vowels and context in Arabic reading especially for low proficiency learners. Some useful implications for teaching reading in Arabic can be introduced. Firstly, improving adult L2 Arabic learners' word recognition can be achieved via incorporating diacritic marks (i.e., short vowels) in all reading materials that are introduced to Arabic learners especially at earliest stages of language acquisition. Unlike third year learners who seem to rely more on reading strategies, the presence of short vowels helped second-year learners read different types of texts more accurately than their unvocalized counterparts. Secondly, results draw teachers' attention to consider the effects of context on learners' reading accuracy when designing and/or selecting tasks to use in their classrooms. Thus, the findings suggest that teachers present a rich amount of reading contexts and design reading activities which facilitate learners' reading of Arabic orthography. Thirdly, L2 Arabic language programs are recommended to include short vowels in their L2 Arabic textbooks for less proficient learners of Arabic.

The current study is limited in terms of being restricted to reading by adult native speakers of English in the United States. More research is needed to examine the robustness of current findings with more groups of learners in different learning contexts. While familiar words were mainly used in the present study, moreover, it is necessary to assess learners' reading accuracy as well as comprehension using novel stimuli that compare frequent versus infrequent words and familiar versus unfamiliar words. Last, future research can also explore whether L2 learners' reading ability of unvocalized Arabic scripts is developed in a longitudinal study. Such studies will further establish a research foundation for evidence-based Arabic language teaching.

\section{Conclusion}

The purpose of the current study was to explore the relevant contribution of short vowels and context to the reading accuracy of non-native adult learners of Arabic at two different proficiency levels: intermediate and advanced. The findings revealed the positive impact of short vowels on the accuracy of less proficient non-native readers of Arabic (i.e., second-year learners) in reading Arabic words, sentences, and paragraphs. Although the reading scores of third-year students were higher than their counterparts in the other group, the difference between the two groups' scores was not statistically significant. Context type was also demonstrated to positively affect the reading performance of the two groups. It can be concluded that reading in Arabic that involves vowelization and context helps English learners of Arabic read different types of Arabic texts.

\section{References}

Abdulhadi, S., Ibrahim, R., \& Eviatar. Z. (2011). Perceptual load in the reading of Arabic: Effects of orthographic visual complexity on detection. Writing Systems Research, 3(2), 117-127. https://doi.org/10.1093/wsr/wsr014

Abu-Hamour, B., Al-Hamouz, H., \& Kenana, M. (2013). The effect of short vowelization on curriculum-based measurement of reading fluency and comprehension in Arabic. Australian Journal of Learning Difficulties, 18(2), 181-197. https://doi.org/10.1080/19404158.2013.852980

Abu-Rabia, S. (1996). The role of vowels and context in reading of highly skilled native Arabic readers. Journal of Psycholinguistic Research, 25(6), 629-641. https://doi.org/10.1007/BF01712413

Abu-Rabia, S. (1997). Reading in Arabic orthography: The effect of vowels and context on reading accuracy of poor and skilled Arabic native readers. Reading and Writing, 9(1), 65-78. https://doi.org/10.1023/A:1007962408827

Abu-Rabia, S. (1998). Reading Arabic texts: Effects of text type, reader type and vowelization. Reading and Writing, 10(2), 105-119. https://doi.org/10.1023/A:1007906222227

Abu-Rabia, S. (2001). The role of vowels in reading Semitic scripts: Data from Arabic and Hebrew. Reading and Writing, 14(1), 39-59. https://doi.org/10.1023/A:1008147606320

Abu-Rabia, S., \& Siegel, L. S. (1995). Different orthographies, different context effects: The effects of Arabic sentence context on skilled and poor readers. Reading Psychology, 16(1), 1-19. https://doi.org/10.1080/0270271950160101

Aebersold, J., \& Field, M. (1997). From reader to reading teacher: issues and strategies for second language classrooms. Cambridge University Press.

Azzam, R. (1989). Orthography and Reading of the Arabic Language. In P. G. Aaron, \& R. M. Joshi (Eds.), 
Reading and Writing Disorders in Different Orthographic Systems (pp. 203-218). Dordrecht: Kluwer Academic Publishers. https://doi.org/10.1007/978-94-009-1041-6_12

Azzam, R. (1993). The nature of Arabic reading and spelling errors of young children. Reading and Writing, 5(4), 355-385. https://doi.org/10.1007/BF01043112

Bruck, M. (1990). Word-recognition skills of adults with childhood diagnoses of dyslexia. Developmental Psychology, 26(3), 439-454. https://doi.org/10.1037/0012-1649.26.3.439

Cairns, C., \& Adams, M. J. (1991). Beginning to read: Thinking and learning about print. Language, 67(2), 388. https://doi.org/10.2307/415121

Carrell, P., Devine, J., \& Eskey, D. (1988). Interactive approaches to second language reading. Cambridge University Press. https://doi.org/10.1017/CBO9781139524513

Hanna, S. A. (1964). Quantitative measurement of errors and remedial instruction in reading Arabic. The Modern Language Journal, 48(6), 349-352. https://doi.org/10.1111/j.1540-4781.1964.tb04511.x

Hansen, G. F. (2008). Visual Word Recognition in Arabic: Towards a Language Specific Reading Model. Syddansk Universitet. Center for Mellemøststudier.

Hansen, G. F. (2010). Word recognition in Arabic as a foreign language. Modern Language Journal, 94(4), 567-581. https://doi.org/10.1111/j.1540-4781.2010.01094.x

Holes, C. (2004). Modern Arabic: Structures, functions, and varieties. Washington, D.C: Georgetown University Press.

Ibrahin, R. (2013). Reading in Arabic: New Evidence for the Role of Vowel Signs. Creative Education, 4(4), 248-253. https://doi.org/10.4236/ce.2013.44036

Khaldieh, S. (1996). Word recognition of Arabic as a foreign language by American learners: The role of phonology and script. Al-Arabiyya, 29(1), 129-159.

Khaldieh, S. (1999). An investigation into reader-text interaction: Native, proficient, and less proficient non-native readers of Arabic. Al-Arabiyya, 32(1), 117-156.

Nation, K., \& Snowling, M. (2004). Beyond phonological skills: Broader language skills contribute to the development of reading. Journal of Research in Reading, 27(1), 342-356. https://doi.org/10.1111/j.1467-9817.2004.00238.x

Perfetti, C. A. (1985). Reading ability. New York: Oxford University Press.

Perfetti, C., \& Rieben, L. (1991). Learning to read. New Jersey: Lawrence Erlbaum Associates Inc.

Prunet, J.F., Be'land, R., \& Idrissi, A. (2000). The mental representation of Semitic words. Linguistic Inquiry, 31(4), 609-648. https://doi.org/10.1162/002438900554497

Ryan, A., \& Meara, P. (1991). The case of the invisible vowels: Arabic speakers reading English words. Reading in a Foreign Language, 7(2), 531-541.

Ryding, K. (2005). A reference grammar of modern standard Arabic. Cambridge: Cambridge University Press. https://doi.org/10.1017/CBO9780511486975

Seraye, A. M. (2004). The Role of Short Vowels and Context in the Reading of Arabic, Comprehension, and Word Recognition of Highly Skilled Reader (Unpublished doctoral dissertation). University of Pittsburgh, Pennsylvania, Pittsburgh.

Seraye, A. M. (2016). Short vowels versus word familiarity in the reading comprehension of Arab readers: A Revisited issue. International Electronic Journal of Elementary Education, 8(3), 481-506.

Taha, H., \& Azaizah-Seh, H. (2017). Visual word recognition and vowelization in Arabic: New evidence from lexical decision task performances. Cognitive Processing, 18(4), 521-527. https://doi.org/10.1007/s10339-017-0830-9

Taha, H. (2016). Deep and Shallow in Arabic orthography: New evidence from reading performance of elementary school native Arab readers. Writing Systems Research, 8(2), 133-142. https://doi.org/10.1080/17586801.2015.1114910

Taouka, M., \& Coltheart, M. (2004). The cognitive processes involved in learning to read in Arabic. Reading and Writing: An Interdisciplinary Journal, 17(1), 27-57. https://doi.org/10.1023/B:READ.0000013831.91795.ec 


\section{Appendix A}

\section{A paragraph Example}

\begin{tabular}{|c|c|}
\hline Vocalized & Unvocalized \\
\hline 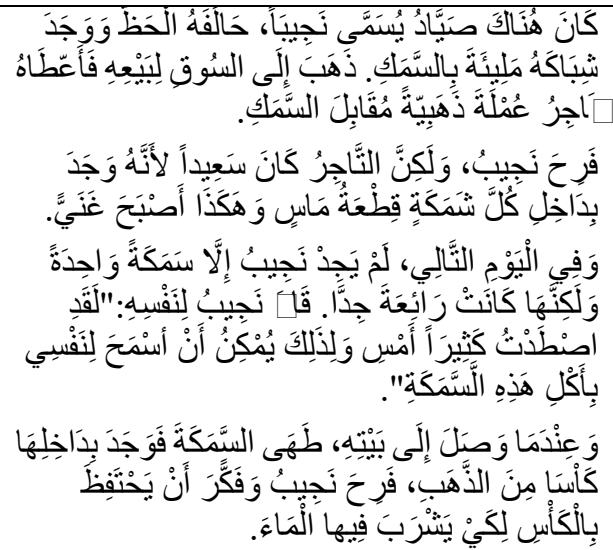 & 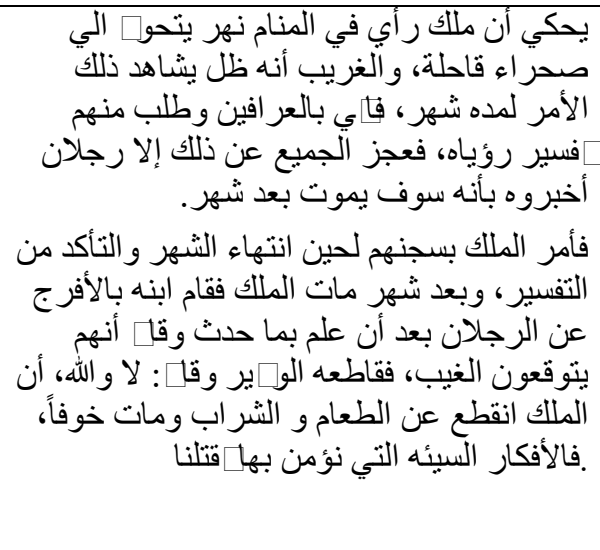 \\
\hline
\end{tabular}

\section{Appendix B}

\section{List of Sentences}

\begin{tabular}{|c|c|}
\hline Vocalized & Unvocalized \\
\hline 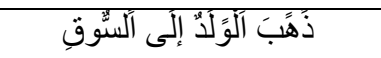 & أكل الرجل ابنه ليلا \\
\hline 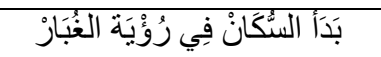 & كل مساهماـي بدون مقابل \\
\hline 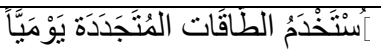 & يفخر الاستاذ بمستوى طلابه \\
\hline 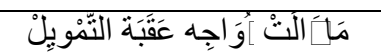 & كتب الضابط رسالة للقاي \\
\hline 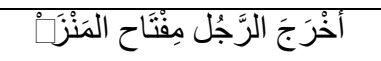 & [و اجه المنطقة ]حديات ثقافية \\
\hline 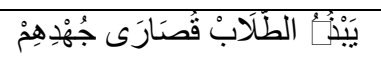 & فاطمة سري سيدة المسرح \\
\hline 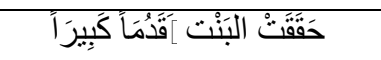 & انفرط عقد القوة العظمى \\
\hline 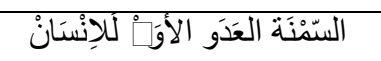 & [ عيم أجنبي يزور البيت الابيض \\
\hline 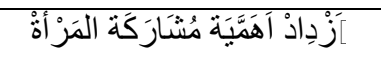 & عملت الطالبة في احدى المكتبات \\
\hline 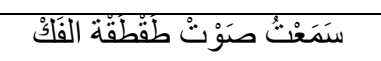 & [زوجت [يجة غير موفقة \\
\hline
\end{tabular}

\section{Appendix C}

\section{List of Individual Words}

\begin{tabular}{|c|c|}
\hline Vocalized & Unvocalized \\
\hline يَتَجَزَاً & يهنئ \\
\hline شَامَلَة & مر ادفات \\
\hline يَهِبُوَ & كتيبات \\
\hline وُجِدَتْْ & مثالية \\
\hline نَرْجُو & الأقصى \\
\hline بِعْعْقْهَهَ & كتفهم \\
\hline مَكَثُشُوفاً & ديانانا \\
\hline قَبَيَلَتْهُهْ & مهزوم \\
\hline قِيَّادَة & الملل \\
\hline حُدُوُوِدهَا & معبر \\
\hline
\end{tabular}




\begin{tabular}{|c|c|}
\hline الرَامَيَة & محامية \\
\hline الأمْنْ & محترمون \\
\hline [َسْوَيَة & حقائق \\
\hline مُبَادَرَةْ & الزام \\
\hline دَعَوَ اتْت & [وجيهات \\
\hline الإنْعِقَاد & الوطن \\
\hline النَوَ اصُل & المرصد \\
\hline قَرَار & متطرفة \\
\hline [َسْجِيِل & [شريعي \\
\hline تُمَنْ & الإذاعة \\
\hline [َسْويَات & مؤسسات \\
\hline يُوَكِدِ & رئاسة \\
\hline لَقِيَ-تُ & [غذي \\
\hline اَحْيَانَاً & محتوى \\
\hline مَفْتَلَ & يصدر \\
\hline
\end{tabular}

\section{Copyrights}

Copyright for this article is retained by the author(s), with first publication rights granted to the journal.

This is an open-access article distributed under the terms and conditions of the Creative Commons Attribution license (http://creativecommons.org/licenses/by/4.0/). 